Barbora Krajčovičová

\title{
Typologické prvky stavieb pre bývanie: Vymedzenie špeciálnych foriem bývania a ich charakteristika
}

Klíčová slova: Typologické prvky; Špeciálne formy bývania; Databáza príkladov foriem bývania.

Kontakt: xakrajcovicova@stud.fa.vutbr.cz

Školitel: Iva Poslušná

Tematický okruh: Architektura

Typological Elements of Housing Structures: Defining Special Types of Housing and Their Characteristics

Housing is one of the most important elements of a person's life. Indeed, it fulfils several basic human needs, described aptly by Maslow's pyramid: the physiological needs, the need for safety and, in a sense, also the need for love and belonging. 


\section{VYMEDZENIE ŠPECIÁLNYCH FORIEM BÝVANIA A ICH}

\section{CHARAKTERISTIKA}

Bývanie je jednou z najdôležitejších častí v živote človeka. Plní totiž zároveň niekol'ko jeho základných potrieb, ktoré sú výborne vystihnuté v Maslowovej pyramíde. Jedná sa konkrétne o plnenie základných telesných, fyziologických potrieb, dalej potrebu bezpečia a istoty a zároveň $\mathrm{v}$ istom zmysle aj lásky a spolupatričnosti.

Dve posledné sú vyjadrené v bývaní ako takom, to znamená, že už samotná schránka vytvára pocit bezpečia a zároveň priestor pre lásku, rodinu. Fyziologické potreby ako dýchanie, regulácia telesnej teploty, pitie, prijímanie potravy, spánok a vylučovanie sa odrážajú práve v typologických prvkoch stavieb pre bývanie. Samozrejme bývanie ako také sa menilo v priebehu času, tak ako sa menila spoločnost', jej kultúra, ekonomické činitele alebo geografické umiestnenie.

Pre vytvorenie si obrazu a pre úplné pochopenie významu istých typologických prvkov je potreba poznat postupný vývoj, pretože mnohé z nich sa transformovali iba postupne. Okrem základných foriem bývania je $\mathrm{v}$ dnešnej dobe zaujímavé zamerat sa na špeciálne formy bývania, medzi ktoré patrí bývanie pre velké rodiny, slobodné matky, bývanie s asistentom, bývanie pre seniorov, handicapovaných, co-housing, domy na pol cesty, bývanie pre Rómov, imigrantov, či väznice a d’alšie, a bližšie ich špecifikovat.

Osobne ma najviac zaujíma trend bývania pre deti rozvedených rodičov so striedavou starostlivostou, pretože fenomén rozvodov narastá. V̌̌etky tieto druhy bývania majú svoje charakteristiky, vyplývajúce z ich náplne, či už sa jedná o dispozičné riešenie alebo stavebnú štruktúru. Súčastou výsledku by mala byt databáza špeciálnych foriem bývania s podrobnejšou analýzou jednotlivých vybraných druhov, ktoré budú mat spoločného menovatela.

\section{SOUPIS ZDROJU゚}

DULLA, Matúš. Kapitoly z historie bydlení. 1. vyd. Praha: České vysoké učení technické v Praze, 2014, 279 s. ISBN 978-80-01-05433-8.

GLOSOVÁ, Soňa. Bydlení pro seniory. 1. vyd. Brno: ERA, 2006, 179 s. ISBN 80-7366-057-1.

JELÍNEK, Jan. Střecha nad hlavou: kořeny nejstarši architektury a bydlení. Vyd. 1. Brno: VUTIUM, 2006, 461 s. ISBN 80-214-2367-6. 
KYNČL, Jakub. 39 bydlení ve městě. 1. vyd. Brno: ERA, 2005, 243 s. ISBN 80-7366-039-3.

MEISS, Pierre von. Elements of architecute: from form to place. 1. vyd. London: Van Nostrand Reinhold, 1990, 211 s. ISBN 0-7476-0014-7.

PROKOPOVÁ, Helena. Byt, který se vám přizpůsobí. 1. vyd. Brno: ERA, 2007, 129 s. ISBN 978-80-01-7366-106-9.

STEMPEL, Jan. 99 domu․ Praha: Kant, 2012, 421 s. ISBN 978-80-01-7437078-6.

\section{FOTOGRAFIE}

Foto: archiv autorky 


\section{Typologické prvky stavieb pre búvanie}

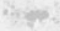

potreba bezpečia a istoty

potrebà lásky

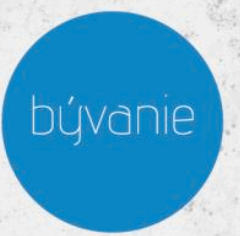

đočasné

- hotely

- ubytovne

- internáty

- hostely

- väznice

- nápravné zariadenia

- azylové domy

- domy na pol cesty

- detské domovy

- utečenecké tábory

\section{bứvanie}

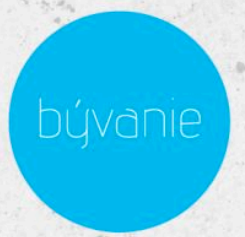

fyziologické a telesné potreby

- dúchanie

- regulácia telesnej teploty

- prijímanie potravy / pitie a jedlo/.

- spánok

- vijlučovanie trvalé

aspekty

- ekonomické

- geografické

- sociálne

- kultúrne.

človek a jeho-vúvoj

0 - cca 19 - búvanie s rodičmi

19- cca 25 - prechodné búvanie (vysoká, prvá práca ..) s $^{x}$

25 - - - vlastné búvanie

65 - - búvanie pre seniorov
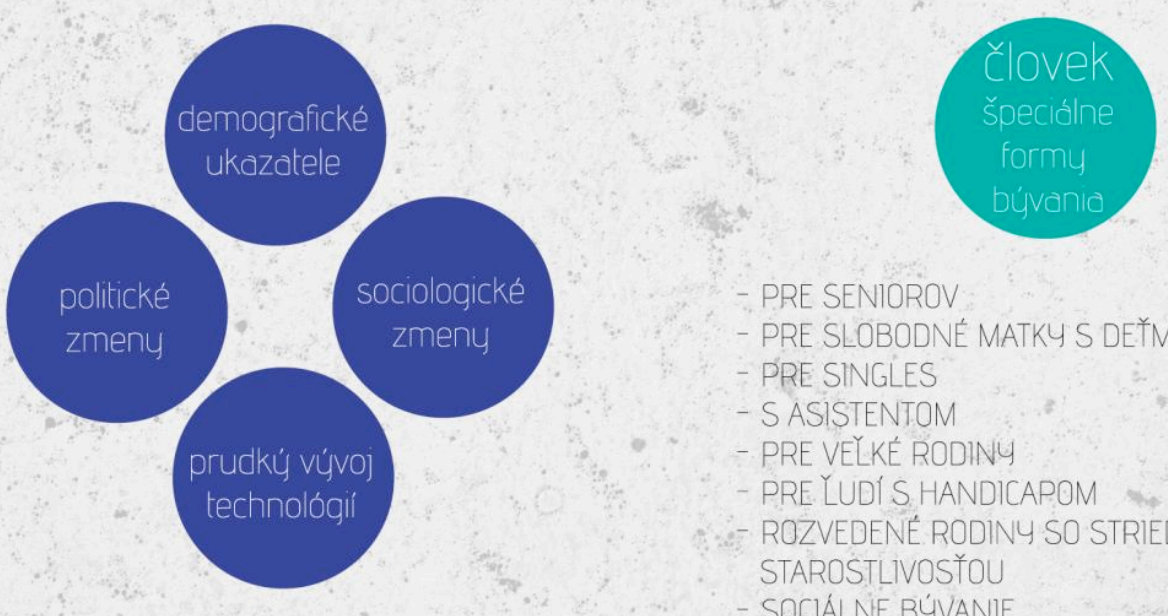

- PRE SENIOROV

- PRE SLOBODNÉ MATKY S DETYMI

- PRE SINGLES

- SASISTENTOM

- PRE VELKÉ RODINY

- PRE LUDI S HANDICAPOM

- ROZVEDENÉ RODINY SO STRIEDAVOU STAROSTLIVOSŤOU

- SOCIÁLNE BÚVANIE

- KOMUNITNÉ BÚVANIE

Každầ z foriem v sebe nesie isté typologické špecifiká, ktoré je treba si definovă̌. 